\title{
A POLÍTICA MIGRATÓRIA BRASILEIRA PARA VENEZUELANOS: DO “RÓTULO” DA AUTORIZAÇÃO DE RESIDÊNCIA TEMPORÁRIA AO DO REFÚGIO (2017-2019)
}

\author{
The Brazilian migration policy for Venezuelans: from the temporary \\ residence permit to the refuge "label" (2017-2019)
}

\author{
Andressa Alves Martino* \\ Julia Bertino Moreira*
}

\begin{abstract}
Resumo. A partir do aporte teórico-conceitual de Roger Zetter acerca do processo de labelling (rotulação) de migrantes, este artigo busca discutir os "rótulos" que foram implementados para gerenciar a atual migração venezuelana para o Brasil no período de 2017 a 2019. Para tanto, utilizamos pesquisa documental e analisamos as autorizações de residência temporária (a Resolução Normativa no 126 de 2017 e a Portaria Interministerial no 9 de 2018) e o reconhecimento da condição de refugiado pela grave e generalizada violação de direitos humanos, ocorrido em 2019. Concluímos que os venezuelanos transitaram entre diferentes "rótulos" mobilizados pelas instituições burocráticas governamentais - solicitante de refúgio, residente temporário até refugiado -, o que ocorreu a partir, especialmente, das últimas mudanças nas diretrizes de política externa brasileira.
\end{abstract}

Palavras-chave: migração venezuelana; Brasil; refúgio; categorias migratórias.

\begin{abstract}
Based on Roger Zetter's theoretical-conceptual contribution about the process of labelling immigrants, this article aims to discuss the "labels" that were implemented to manage the current Venezuelan immigration to Brazil in the period from 2017 to 2019. To do so, we used documentary research and analyzed temporary residence permits (Resolução Normativa $n^{\circ}$ 126 and Portaria Interministerial $n^{\circ}$ 9) and the recognition of refugee status grounded on gross and generalized violation of human rights. We conclude that Venezuelans have transitioned between different "labels" mobilized by government bureaucratic institutions - as a temporary resident and asylum
\end{abstract}

\footnotetext{
Mestranda no Programa de Pós Graduação em Ciências Humanas e Sociais da Universidade Federal do ABC. São Bernardo do Campo, SP, Brasil. E-mail: andressamartino@gmail.com. Orcid: https://orcid.org/0000-0003-2554-2503.

** Professora de Relações Internacionais e dos Programas de Pós-graduação em Ciências Humanas e Sociais e de Relações Internacionais da Universidade Federal do $\mathrm{ABC}$, vinculada à Cátedra Sérgio Vieira de Mello da mesma universidade. São Bernardo do Campo, SP, Brasil. E-mail: julia. bertino@ufabc.edu.br. Orcid: https://orcid.org/0000-0003-3951-508X.
} 
seeker to refugee - this occurred, especially, from the latest changes in Brazilian foreign policy guidelines.

Keywords: venezuelan immigration; Brazil; refuge; migratory categories.

\section{Introdução}

Em virtude do acirramento de crises político-econômicas na Venezuela, especialmente desde meados de 2015, o Brasil tem se tornado um país de destino para migrantes venezuelanos. Neste texto pretendemos apresentar e refletir sobre a atual política migratória brasileira adotada para gerenciar esse movimento que, nos últimos anos, engloba mais de 250 mil pessoas (ACNUR, OIM, 2020). São analisadas as medidas de Autorização de Residência Temporária (Resolução Normativa no 126 do Conselho Nacional de Imigração (CNIg) e Portaria Interministerial no 9) que foram instituídas em 2017 e 2018, respectivamente; e a decisão do Comitê Nacional para Refugiados (CONARE), em 2019, segundo a qual a atual situação na Venezuela deve ser compreendida como uma grave e generalizada violação de direitos humanos, cláusula prevista para o reconhecimento de refúgio pela lei brasileira. Consideramos que a concessão de autorização de residência temporária e o reconhecimento da condição de refugiado são possibilidades distintas de regularização migratória, não apenas devido à sua fundamentação jurídica (baseadas na Lei de Migração no 13.445/17 e na Lei de Refúgio no 9.474/97, respectivamente), mas também pelos efeitos práticos que acarretam para a população migrante que as vivenciam.

Como referencial analítico recorremos ao aporte teórico-conceitual de Roger Zetter (2007) acerca do processo de labelling (rotulação) de migrantes, a fim de melhor compreendermos como o movimento migratório venezuelano foi gerido no Brasil. Segundo o autor, os Estados gerenciam os fluxos imigratórios para seu território por meio do enquadramento dessas pessoas em "rótulos", isto é, classificações burocráticas migratórias. Estes podem ser amparados em bases regulatórias distintas, refletem diferentes possibilidades de acesso a direitos e são mobilizados de acordo com as orientações de política interna e externa desses Estados. Como consequência, certa hierarquia se estabelece entre os rótulos, na medida em que alguns são priorizados em relação aos demais, como é o caso do "rótulo" do refúgio que, na perspectiva do autor, atualmente tem se tornado um dos mais difíceis de ser alcançado pelos migrantes, visto que, cada vez mais, os Estados optam por medidas de proteção complementar ao invés de incluir os migrantes no escopo do refúgio. Desse modo, migrantes são levados a transitar entre os diferentes "rótulos" em busca de regularização no país receptor. 
A partir da chave conceitual proposta por Zetter, trabalhamos com a seguinte questão de pesquisa: como a política migratória foi implementada e foi se modificando ao longo dos últimos anos em relação aos venezuelanos no Brasil? Temos como hipótese que foram construídos e atribuídos diferentes "rótulos" a essas pessoas até se chegar à decisão de se reconhecer o refúgio, o que também parece ter sido possível somente à luz da reorientação da política externa brasileira direcionada à Venezuela, como examinamos a seguir.

A atuação brasileira frente aos desafios postos pela imigração venezuelana tem sido tema de muitos estudos (Baeninger et al., 2018; Silva, 2018), porém, poucos são os balanços que incluem e sistematizam a decisão pelo refúgio (Moreira, 2019; Pereira, 2020; Silva, Abrahão, 2019; Souza, 2019), propósito deste trabalho. O texto está dividido em três seções. Na primeira, discutem-se o contexto e as implicações da adoção da autorização de residência temporária aos migrantes venezuelanos; em seguida, propõe-se analisar a decisão de reconhecer a condição de refugiado pela via da grave e generalizada violação de direitos humanos; por fim, na terceira seção, aplicam-se os pressupostos teóricos de Zetter para se interpretar a política migratória implementada para gerenciar o fluxo venezuelano no Brasil. Os métodos e materiais de pesquisa consistem em revisão bibliográfica e pesquisa documental (legislações, estatísticas, relatórios disponibilizados por órgãos governamentais e organismos internacionais, além de notícias de jornais).

\section{Da concessão de autorização de residência temporária}

A instabilidade política, econômica e social decorrente da crise que a Venezuela vem enfrentando desde 2015 provocou a emigração de mais de 4,5 milhões de pessoas até o final de 2019, de acordo com dados do Alto Comissariado das Nações Unidas para Refugiados (ACNUR, 2020). Os venezuelanos têm se deslocado, majoritariamente, para os países vizinhos ${ }^{1}$ na América do Sul, em especial, para Colômbia, Peru, Chile, Equador e Brasil (ACNUR, 2020; ACNUR, OIM, 2020).

Controvérsias conceituais marcam o debate institucional e acadêmico a respeito de como categorizar o fluxo venezuelano (Freier, 2018), devido à difícil distinção entre migração forçada ou voluntária - situação cada vez mais comum na contemporaneidade. Não à toa o termo "fluxo misto" tem sido frequentemente empregado por pesquisadores (Rossa, Menezes, 2018) e vem sendo aplicado para compreender também o caso dos venezuelanos (Silva, Bógus, Silva, 2017). Da mesma forma, os referenciais teóricos da "migração

\footnotetext{
1 Segundo dados da Organização Internacional para as Migrações (OIM) e do ACNUR, até outubro de 2020, já migraram para a Colômbia aproximadamente 1,8 milhão de venezuelanos; para o Peru, mais de 1 milhão; para o Chile, mais de 450 mil e para o Equador mais de 415 mil pessoas (ACNUR, OIM, 2020).
} 
por sobrevivência" (Betts, 2013) e "de crise" (Martin, Weerasinghe, Taylor, 2014) auxiliam na interpretação de movimentos migratórios permeados por vulnerabilidades econômicas e sociais².

No tocante ao Brasil, ingressaram mais de 250 mil venezuelanos até agosto de 2020 e, diante deste cenário, interessa-nos saber como o Estado brasileiro incorporou tais discussões e quais medidas migratórias foram implementadas (ACNUR, OIM, 2020). A questão que se colocava no início deste movimento migratório, especialmente entre 2015 e 2016, era se a regularização ocorreria pelo reconhecimento do status de refugiado ou pela via da proteção complementar (Jubilut, Fernandes, 2018). Aqueles que se posicionavam a favor do refúgio, como Jubilut e Fernandes, compreendiam que as pessoas estavam fugindo da Venezuela, razão pela qual teriam o direito de pleitear a proteção estatal brasileira, com base nos critérios tradicionais de elegibilidade referentes a fundados temores de perseguição; ou, pelos preceitos inspirados na Declaração de Cartagena, por meio do reconhecimento da grave e generalizada violação de direitos humanos ${ }^{3}$.

A possibilidade da regularização dos venezuelanos pela via do refúgio, porém, na perspectiva de Silva (2018), era "improvável" na época, devido ao entendimento de que a situação do país não produzia perseguições individuais e de que o governo brasileiro não caminhava politicamente em direção ao reconhecimento da cláusula de Cartagena. Essa resistência em se aplicar a grave e generalizada violação de direitos humanos tem levado pesquisadores, como Laura Sartoretto (2018), a afirmar que, embora a lei de refúgio nacional seja considerada uma das mais inclusivas da região, sua interpretação e prática são geralmente conservadoras e restritivas.

Ainda que não houvesse um indicativo de que seriam julgadas procedentes, as solicitações de reconhecimento da condição de refugiado (doravante, solicitações de refúgio) estavam sendo mobilizadas pelos venezuelanos e pelas instituições locais provedoras de apoio a migrantes, especialmente nas cidades fronteiriças de Boa Vista e Pacaraima. Trata-se de um processo gratuito, sem

2 A expressão "migração de sobrevivência", cunhada por Betts (2013), refere-se a fluxos de "pessoas que estão fora de seu país de origem devido a uma ameaça existencial para qual elas não possuem acesso às resoluções ou remediações internas" (p. 4-5). Por sua vez, o conceito de "migração de crise" visa contemplar deslocamentos oriundos de crises humanitárias, que estão além do controle dos indivíduos em suas múltiplas facetas (Martin, Weerasinghe, Taylor, 2014).

A lei de refúgio brasileira define que será reconhecido como refugiado todo indivíduo que se deslocar devido a "fundados temores de perseguição por motivos de raça, religião, nacionalidade, grupo social ou opiniões políticas", incluindo-se nesse quesito a situação de apatridia; ou à situação de grave e generalizada violação de direitos humanos em seu país de origem (BRASIL, 1997). Os dois primeiros critérios são considerados clássicos por integrarem os princípios da Convenção de Genebra de 1951 e o último baseia-se na Declaração de Cartagena de 1984 que, em suas recomendações originais, visava ampliar o escopo de proteção da Convenção em âmbito regional. 
a exigência de apresentação de documentos do país de origem e que resulta, após a formalização do pedido, em um documento de identificação provisório (popularmente conhecido como protocolo de solicitação de refúgio) que garante a seus portadores estar em situação regular no país enquanto aguardam a análise da decisão sobre o reconhecimento da condição de refugiado (BRASIL, 1997).

Com posse do protocolo, os migrantes passam a sustentar o status de solicitante de refúgio e, em razão disso, têm o direito de acessar serviços de saúde, educação, assistência social, além de também poderem exercer atividade remunerada no país. O pedido de refúgio é analisado pela coordenação do CONARE, que não oferece um prazo para tramitação do processo. Em caso de indeferimento, o solicitante tem direito a recurso e, mesmo nesta etapa, permanece com seu protocolo (BRASIL, 1997). Estima-se que, atualmente, por conta do backlog 4 (quantidade de solicitações de refúgio pendentes) do CONARE, os pedidos de refúgio levam em média três anos para serem julgados em primeira instância (BRASIL, 2020c). Durante 2015 e 2016, mais de 4 mil novas solicitações de venezuelanos foram registradas, mas apenas 18 delas foram deferidas (BRASIL, 2018b). Esse número tão escasso parece ser um indicativo de que, neste período, ainda não havia um consenso por parte do governo brasileiro sobre como os pedidos de refúgio dos venezuelanos seriam avaliados.

Silva (2018) aponta que, somente após reivindicações de instituições da sociedade civil e de governos locais por uma política migratória mais definitiva, é que o Estado brasileiro - por meio do CNIg, órgão vinculado ao então Ministério do Trabalho e Emprego (MTE) responsável historicamente pela gestão da migração econômica e laboral no país - publicou a Resolução Normativa (RN) no 126, de 02 de março de 2017, para gerenciar a questão mediante a concessão de residência temporária. Vejamos:

Considerando os objetivos que inspiraram o Acordo sobre Residência para Nacionais dos Estados Partes do MERCOSUL e Países Associados, [...] considerando o fluxo migratório a unidades da Federação, sobretudo na região Norte, de estrangeiros nacionais de países fronteiriços que ainda não são parte do referido Acordo de Residência, que se encontram em situação migratória irregular no Brasil e aos quais não se aplica o instituto do refúgio para permanecer no país, resolve:

Art. 10 Poderá ser concedida residência temporária, pelo prazo de até 2 anos, ao estrangeiro que tenha ingressado no território brasileiro por via terrestre e seja nacional de país fronteiriço, para o qual ainda não esteja em vigor o Acordo de Residência para Nacionais dos Estados Partes do MERCOSUL e países associados. [...]

Art. $2^{\circ} \mathrm{O}$ estrangeiro que pretenda se beneficiar da presente Resolução Normativa e tenha solicitado refúgio no Brasil deverá apresentar às unidades da Polícia Federal declaração de preferência de regularização de estada, indicando como fundamento de seu pedido esta Resolução Normativa. (BRASIL, 2017, grifos nossos)

\footnotetext{
4 Segundo dados do CONARE, até outubro de 2020, 187.983 solicitações de refúgio ainda estavam em trâmite (BRASIL, 2020d).
} 
O primeiro dos pontos a serem destacados é que a RN não mencionava a Venezuela, embora tivesse sido elaborada com intuito de regulamentar o fluxo desses migrantes (Silva, 2018). Para tanto, o documento recuperou e expandiu princípios de integração regional do MERCOSUL, do qual o país foi associado, de 2012 a 2016, até ser suspenso em função da denominada cláusula democrática (Marchao, 2017).

A RN se colocava como destinada àqueles em "situação irregular" ou "a quem não se aplicam os critérios da Lei de Refúgio". Com isso, percebe-se a intenção de se ofertar uma medida que contemplasse os migrantes venezuelanos que, até então, estavam em um limbo migratório, isto é, estavam na condição provisória de solicitante de refúgio, mas ainda sem terem uma previsão de que o reconhecimento do refúgio aconteceria em definitivo. Ainda, no segundo artigo da resolução, consta que o migrante deveria optar por qual política migratória desejava se regularizar, seja pela residência provisória ou pela solicitação de refúgio, o que pode ser entendido como uma tentativa de dificultar o acesso ao refúgio ${ }^{5}$, o que se articula com a análise de Zetter (2007).

O ingresso no território brasileiro por via terrestre era outro entrave da resolução, por não incluir aqueles que se utilizavam da via aérea ou marítima para chegar ao Brasil como possíveis destinatários da $\mathrm{RN}$, embora proviessem de conjunturas similares daqueles que optaram pelo trânsito terrestre. A RN determinava a entrada pelas cidades fronteiriças como condição obrigatória para regularização migratória dos venezuelanos. Com esta medida, todos os migrantes, mesmo aqueles que desejassem ir a outras localidades no país, deveriam passar por Pacaraima ou Boa Vista, o que gerou sobrecarga à estrutura burocrática dessas cidades (Silva, 2018). Além destes, também foram pontos de discussão as taxas cobradas para obtenção da residência temporária (revogadas em julho do mesmo ano) e a exigência de documentação ${ }^{6}$. Finalmente, destaca-se que a RN estabelecia residência temporária apenas por $2 \operatorname{anos}^{7}$ e as condições para possíveis renovações não haviam sido indicadas (BRASIL, 2017).

5 Esta condição está presente em outras medidas de proteção complementar que o CONARE vem adotando desde o final de 2018 na tentativa de reduzir seu backlog. Dentre elas, destacam-se a Resolução Conjunta no 01 do CONARE e do CNIg, de 09 de outubro de 2018, que dispõe sobre autorização de residência a migrantes que tiveram carteira de trabalho assinada e solicitaram refúgio antes de 21 de novembro de 2017 (data da promulgação da nova Lei de Migração); a Portaria Interministerial no 4, de 26 de julho de 2019, para nacionais de Cuba, integrantes do Programa Mais Médicos; Portaria Interministerial no 5, de 26 de julho de 2019, para nacionais da República Dominicana; e a Portaria Interministerial no 10, de 05 de dezembro de 2019, para nacionais da República do Senegal.

6 A exigência de documentação era um obstáculo sobretudo para a população migrante mais vulnerável socioeconomicamente e para os povos indígenas também presentes no fluxo venezuelano fronteiriço (Simões, 2017).

7 Esta mesma prerrogativa foi utilizada com o "visto com base em razões humanitárias" criado em 2012 especificamente para os migrantes haitianos (Sartoretto, 2018). 
Somente um ano depois, em 14 de março de 2018, foi publicada a Portaria Interministerial (PI) no 9 com fins de substituição da RN no 126 do CNIg. A portaria, enfim, cedeu a diversas das críticas feitas à resolução: excluiu a exigência da via terrestre, modificou a documentação demandada no caso de pessoa indígena, manteve a gratuidade de acesso a quem pudesse comprovar hipossuficiência econômica e também transformou a residência temporária para indeterminada ao término dos dois primeiros anos - considerado um dos mais significativos aprimoramentos dessa normativa ${ }^{8}$ (BRASIL, 2018a). Dessa forma, a autorização de residência se tornou uma estratégia de proteção complementar mais consistente ofertada aos venezuelanos.

Apesar disso, os migrantes continuaram buscando regularização migratória pela via da solicitação de refúgio haja vista que, ao final de 2018, foram computados 61.681 pedidos pendentes, o que representa um aumento de $7.403 \%$ em relação aos dados de 2015 (BRASIL, 2019c). Silva (2018) e Simões (2017) justificam tal fenômeno devido à exigência de documentação do país de origem, a qual, embora tivesse sido reduzida pela $\mathrm{Pl}$, ainda não se comparava com a solicitação de refúgio, isenta desse tipo de condição; e à facilidade de acesso à regularização brasileira pelo protocolo de refúgio, ainda que em caráter provisório. Nota-se, portanto, que um dos principais objetivos da RN no 126 e da PI no 9 - o de se tornar uma alternativa ao refúgio - não se concretizou. Para os autores, as medidas de autorização de residência ainda eram insuficientes para administrar a situação.

\section{Da decisão pelo refúgio com base em grave e generalizada violação de direitos humanos}

O tema das migrações no Brasil sofreu impactos quando Jair Bolsonaro assumiu a presidência em 2019. Ao longo do ano, foram adotadas diversas medidas que apontavam para a retomada de uma visão securitária da migração, como: a saída do Pacto Global das Migrações logo após sua posse em janeiro; as publicações das Portarias no 666 e no 770, que tratam das condições para impedimento de ingresso, repatriação e a deportação de "pessoa perigosa"; e a cessação do status de três refugiados paraguaios que haviam sido perseguidos por razões políticas em seu país de origem (Mendes, Menezes, 2019; Souza, 2019). Além disso, mudanças significativas ocorreram em termos de política externa, especialmente nas relações com os países aos quais o atual governo se

\footnotetext{
8 A PI no 9 sofreu algumas alterações publicadas posteriormente pela PI no 15, de 27 de agosto de 2018, e pela PI no 2, de 15 de maio de 2019. A primeira dispensa a documentação de país de origem requisitada para migrantes em situação de vulnerabilidade, e a segunda facilita a entrada de crianças venezuelanas, além de determinar que a obtenção da autorização de residência temporária implica na desistência da solicitação de refúgio.
} 
opõe político-ideologicamente, como é o caso da Venezuela (Moreira, 2019; Pereira, 2020).

Tendo em vista esse novo contexto, em plenária realizada em 13 de junho de 2019, a coordenação do CONARE produziu uma nota técnica com base no Estudo de País de Origem, defendendo que a situação venezuelana fosse considerada como grave e generalizada violação de direitos humanos (BRASIL, 2019a). O CONARE fez, então, as seguintes recomendações:

1. Adotar procedimentos simplificados para a tramitação dos processos de reconhecimento da condição de refugiado de nacionais venezuelanos;

2. Que seja mantida a indispensabilidade de entrevista de elegibilidade, devendo esta ocorrer ainda que de maneira simplificada;

3. Que seja mantida a indispensabilidade de verificação de excludentes, com base no art. 3 o da Lei no 9.474/97. Sobre este ponto, mister recordar também que a nota de orientação do Acnur reconhece que a condição de refugiado conforme Cartagena não se aplicaria a membros de colectivos e megabandas, entre outros grupos de guerrilha urbana, bem como membros de grupos criminosos organizados e pessoas que se beneficiam materialmente das circunstâncias na Venezuela; [...]

6. Por fim, considerando as mudanças no contexto interno do país, sugere-se que a atualização da decisão seja feita, no mínimo, após transcorridos 12 meses, a contar da data de decisão inicial pelo Comitê Nacional para os Refugiados, com a ressalva de que pode ser feita a qualquer momento caso haja mudança no contexto fático do país. (BRASIL, 2019a, p. 13, grifos nossos)

A decisão pela aplicação da cláusula de Cartagena foi celebrada por diversas instituições da sociedade civil e internacionais (ACNUR, 2019), especialmente, por ser compreendida como uma política migratória mais definitiva (Jubilut, Fernandes, 2018). Como refugiados, os venezuelanos, além de gozarem da proteção estatal brasileira, passariam a usufruir de um "sistema mais robusto de proteção e integração social, o que facilita o acesso à regularização, à assistência e a equipamentos públicos" (Pereira, 2020), além de terem direito à reunificação familiar e estarem protegidos pelo princípio de non-refoulement ${ }^{9}$ - o que não é previsto em nenhuma outra modalidade migratória (BRASIL, 1997).

Entretanto, como a proteção do refúgio só é válida em território brasileiro, coloca-se o ônus da necessidade de autorização para viagens ao país de origem ${ }^{10}$, o que, no caso da pendularidade característica do fluxo venezuelano $^{11}$, pode representar um entrave significativo na manutenção da

9 Trata-se de um direito garantido aos solicitantes de refúgio e refugiados de não serem devolvidos para fronteiras de territórios em que sua vida ou liberdade esteja ameaçada (BRASIL, 1997).

${ }^{10}$ A autorização de viagem é um procedimento obrigatório para refugiados que vivem no Brasil e desejam viajar para seu país de origem; para qualquer destino por mais de 12 meses; e/ou com o passaporte de origem como documento de viagem. A ausência da autorização não impede a partida e o retorno do refugiado ao Brasil, porém pode implicar na instauração do processo de perda do status de refugiado (BRASIL, 2016).

${ }^{11}$ A referida pendularidade diz respeito ao cruzamento de fronteiras terrestres entre a cidade 
regularização migratória dessas pessoas (Silva, 2018). Ademais, a regularização por meio do refúgio se mantém apenas enquanto existirem as circunstâncias que provocaram a necessidade de proteção, em contrário, é possível que se determine a cessação de tal status (BRASIL, 2019a) ${ }^{12}$.

Em 3 de dezembro de 2019, o CONARE publicou um aditamento à referida nota técnica com intuito de anunciar a adoção do reconhecimento prima facie ${ }^{13}$ para determinação do refúgio dos venezuelanos (BRASIL, 2019b). Tal procedimento prevê decisões coletivas, quando não se é possível processar a elegibilidade individualmente devido à urgência na assistência. Para tanto, o CONARE optou pelo cruzamento de banco de dados da Polícia Federal (PF), do Ministério Justiça Segurança Pública (MJSP) e de antecedentes criminais dos solicitantes para analisar um agrupamento de casos similares selecionados pelo comitê (Grillo, 2019). Dessa forma, foram priorizados os venezuelanos que já estavam no Brasil e ainda não obtiveram a autorização de residência por meio de outra condição migratória (como a da PI no 9). Assim, o CONARE anunciou o reconhecimento em massa de mais de 21 mil venezuelanos em 6 de dezembro e, posteriormente, em 31 de janeiro e em agosto de 2020, outros 17 mil e 7,7 mil respectivamente foram reconhecidos de uma só vez (BRASIL, 2020b). A metodologia aplicada foi explicada por André Furquim, diretor do Departamento de Migrações do MJSP:

- Quando a gente chegou no perfil considerado seguro para conceder o benefício, a gente ainda fez uma avaliação de antecedentes (criminais), por meio de cruzamento com vários bancos de dados existentes, porque a lei de refúgio prevê situações em que as pessoas não podem ser beneficiadas pelo instituto. O que foi apresentado aos integrantes do Conare: "Olha, nós temos segurança de dizer para os senhores que a gente tem esses processos com esse perfil, então os senhores podem deliberar a respeito da condição de refúgio". (Grillo, 2019)

André Furquim, em sua declaração, refere-se às possibilidades de exclusão previstas na lei de refúgio, mediante as quais quem cometeu crimes contra a paz, crime de guerra, crimes contra a humanidade e/ou participou de atos terroristas ou tráfico de drogas não pode usufruir da proteção e demais direitos do refúgio no Brasil (BRASIL, 1997). No caso dos migrantes venezuelanos, o item 3 da nota técnica especifica que ser membro de colectivos, megabandas ou grupos de guerrilha urbana, entre outros, é condição suficiente para exclusão (BRASIL, 2019a). O cruzamento dos dados dos solicitantes, portanto,

venezuelana Santa Elena de Uairén e a brasileira Pacaraima. As condições de viagem são determinantes neste caso, pois os venezuelanos não se verão impedidos, na prática, de sair do Brasil, porém poderão ter sua regularização migratória comprometida ao retornar (Pereira, 2020).

12 Em agosto de 2020, o CONARE decidiu renovar por mais 12 meses a decisão de reconhecer os venezuelanos como refugiados pela grave e generalizada violação de direitos humanos (BRASIL, 2020b).

${ }^{13}$ Tal procedimento já havia sido adotado, em 2015, em virtude do número expressivo de migrantes sírios que pediram refúgio no Brasil (Correa et al., 2015). 
objetiva filtrar os casos que necessitam de análises mais aprofundadas sobre tais determinantes, e também acelerar o julgamento das solicitações que foram consideradas compatíveis com os critérios para inclusão no refúgio.

Com o reconhecimento prima facie, o Brasil se tornou o país da América Latina com o maior número de refugiados venezuelanos reconhecidos da região com um total acumulado de mais de 50 mil pessoas até agosto de 2020 (BRAZIL, 2020b). Tal aumento reverbera internacionalmente uma imagem positiva, de boas práticas e de abertura ao acolhimento de pessoas em situação de vulnerabilidade. Contudo, tal procedimento também merece atenção, visto que maiores detalhes acerca da seleção desses primeiros grupos de venezuelanos reconhecidos - como idade, gênero, local de entrada no Brasil, tempo de espera da solicitação -, não foram divulgados e tal discrição é resguardada pelo caráter sigiloso dos processos de elegibilidade do CONARE. A falta de transparência, porém, alerta para as ambiguidades que possam existir, tanto no reconhecimento do refúgio como em eventuais cessações. Isto porque, como se dialoga com Zetter, os "rótulos" são mobilizados enquanto são úteis politicamente.

Neste contexto, considerando que a definição ampliada de refúgio era reivindicada por diversos atores sociais desde o início da crise venezuelana em 2015, é imperativo refletir acerca deste processo e das condições que levaram à decisão em 2019. Nesse sentido, é possível que sua aplicação tenha ocorrido somente naquele momento, pois encontrou um "ambiente propício, politicamente conveniente", como avalia Souza (2019, p. 42). Afinal, reconhecer a condição de refugiados aos venezuelanos pode ser entendido como parte da estratégia do governo Bolsonaro em se opor, nos planos doméstico e internacional, às políticas alinhadas ao espectro político-ideológico da esquerda (Moreira, 2019). Tanto assim que, em janeiro de 2020, Jair Bolsonaro discursou a favor da necessidade de garantir proteção aos "irmãos venezuelanos" que fugiram da "miséria", do "populismo" e da "crise do regime [do presidente Nicolas] Maduro". Disse ainda que a oposição, representada pelo governo do Partido dos Trabalhadores (PT), não teria acolhido os migrantes venezuelanos e finalizou sua fala com "Brasil e Venezuela acima de tudo. Deus acima de todos", slogan de sua campanha presidencial (BRASIL, 2020a).

Com isso, Pereira (2020) afirma que "o compromisso do atual governo não é com imigrantes e refugiados, mas exclusivamente com sua claque e a batalha anticomunista que trava, quixotescamente". Isto porque:

Classificar tais migrantes como refugiados e refugiadas implica denunciar o país de origem - ou seja, a Venezuela - como Estado que não respeita os direitos mais básicos de sua população e, portanto, não se constitui como democrático. Nesse sentido, mobilizou-se o refúgio como parte da estratégia do posicionamento político perante a comunidade internacional em relação ao país vizinho. (Moreira, 2019) 


\section{O processo de labelling (rotulação) de migrantes aplicado ao caso venezuelano}

A fim de melhor compreendermos como o movimento migratório venezuelano foi gerido no Brasil, recorremos a um referencial conceitual que oferece importantes insights sobre o caso em análise. Roger Zetter (2007) concebe o processo de rotulação de migrantes como uma prática de gestão governamental que, ao interpretar as nuances dos fluxos migratórios, determina o seu devido meio de regularização com base na implementação de instrumentos vigentes ou com a criação de novos dispositivos. O autor afirma ainda que essas análises são imbricadas nos interesses estatais de política doméstica e externa dos países receptores e que, portanto, os "rótulos" aplicados aos migrantes não podem ser considerados "neutros", à medida que representam posicionamentos políticos.

Partindo do "rótulo" refugiado, Zetter sustenta que, a despeito desta categoria ter sido institucionalizada pela Convenção de 1951, autoridades estatais a mobilizam, na atualidade, com o fim político de selecionar aqueles que poderão, de fato, acessá-la. Em sua perspectiva, criou-se uma hierarquia entre as categorias migratórias, em que o refúgio se tornou a mais privilegiada delas e, portanto, a mais difícil de ser alcançada. Isso se deve, principalmente, ao fato de que, ao reconhecer uma pessoa como refugiada, o Estado assume um compromisso perante a comunidade internacional de lhe garantir assistência e proteção (Sartoretto, 2018). O autor identifica que os Estados buscam "fracionar" o instituto do refúgio, o que se percebe nas medidas de concessão de proteção complementar e de residência temporária instituídas discricionariamente por autoridades governamentais. Para Zetter (2007, p. 189), este é um meio de inibir o acesso ao refúgio, da mesma forma que a condição provisória de solicitante de refúgio "atua como reservatório para conter a entrada e interceptar o acesso à reivindicação mais premiada".

O caso venezuelano evidencia o tratamento discricionário das instituições burocráticas ao gerenciar movimentos migratórios que escapam dos critérios tradicionais e são tidos como fluxos mistos. Não à toa, as interpretações e as medidas implementadas foram distintas nos países latinoamericanos que receberam migrantes venezuelanos, assim como os "rótulos" a eles atribuídos. Até 2018, Colômbia, Peru e Equador criaram mecanismos de residência temporária, Chile optara pela emissão de vistos específicos para venezuelanos; Argentina e Uruguai ofereceram residência baseada em cláusulas do MERCOSUL, e somente o México decidira pelo refúgio aplicando Cartagena (Brenner, Frouws, 2018; Freier, 2018). Neste período, também o Brasil concedia apenas proteção complementar pela via da autorização de residência temporária, muito embora os venezuelanos continuassem a tentar 
acessar o refúgio, assumindo provisoriamente a condição de solicitantes. Como analisam Jubilut e Fernandes:

\begin{abstract}
Verifica-se, assim, uma preferência dos Estados da região por formas de proteção complementar para os Venezuelanos como meio de regularização migratória. Se por um lado, tais medidas podem ser mais ágeis, e em alguns casos mais simplificadas, que os procedimentos para a determinação do status de refugiado, por outro lado, podem ser vistas como uma maneira dos Estados diminuírem suas responsabilidades uma vez que o Direito Internacional dos Refugiados traz deveres mais amplos em termos de proteção a esses migrantes forçados e podem levar a diminuições nos direitos dessas pessoas, tanto em termos de entrada e estada nos territórios quanto em termos de proteção integral. (Jubilut, Fernandes, 2018, p. 175)
\end{abstract}

A adoção da proteção complementar em detrimento do refúgio no Brasil vai ao encontro da análise de Zetter, considerando que, apesar de o refúgio ter sido reconhecido em 2019, outras medidas foram priorizadas até que finalmente se procedesse ao reconhecimento dos venezuelanos como refugiados. Aos migrantes coube a tarefa de transitar, de 2017 a 2019, entre os "rótulos" de solicitante de refúgio, residente temporário até conseguirem acessar, então, o de refugiado, pois institucionalmente, houve modificações nas interpretações burocráticas que levaram o caso a circular entre o CNIg e o CONARE.

Os obstáculos impostos em termos de acesso ao refúgio podem ser interpretados como uma política estatal restritiva de preservação do "rótulo" de refugiado, como se observa em Zetter. Com tais medidas, verifica-se que cada vez mais pessoas permanecerão transitando entre os "rótulos" de solicitante de refúgio e outros que forem sendo instituídos discricionariamente a partir dos interesses políticos do país receptor. Como mostrou o caso venezuelano, a não ser que haja uma mudança significativa em termos de política externa no país de acolhida, o refúgio, sendo uma categoria inerentemente permeada por aspectos políticos, continuará a ser a mais privilegiada e, portanto, de mais difícil acesso.

\title{
Considerações Finais
}

Buscamos, neste artigo, discutir os mais recentes instrumentos adotados pelo Estado brasileiro em termos de política migratória para os imigrantes venezuelanos que têm se deslocado para o Brasil devido ao agravamento da crise político-econômica iniciada em 2015 e que perdura até hoje. Para gerenciar a situação dos mais de 250 mil migrantes venezuelanos vivendo no país, o governo federal optou por diferentes medidas de "rotulação" (Zetter, 2007), passando da concessão de autorização de residência temporária até a decisão de que a conjuntura venezuelana deveria ser compreendida como uma grave e generalizada violação de direitos humanos, podendo assim ser enquadrada como um caso de refúgio. 
Interpretar a política brasileira para venezuelanos a partir da proposta teórico-conceitual de Zetter nos permitiu reconhecer que "rótulos" foram criados e mobilizados para gerir este fluxo imigratório até se deliberar pelo "rótulo" do refúgio, conforme as diretrizes de política externa brasileira foram se modificando nos últimos anos. Assim, as instituições burocráticas foram conduzindo tal população migrante a transitar entre as categorias de regularização conforme estas eram disponibilizadas pelo CNIg e pelo CONARE. Contudo, cabe destacar que a adesão a determinado "rótulo" implica anuir às diferentes condições próprias de cada categoria, como vistas anteriormente. Logo, o processo de rotulação não diz respeito apenas a uma formalidade institucional, mas sim sobre como os migrantes vivenciam sua estada no Brasil.

A resistência em se aplicar a definição ampliada de refúgio também pode ser apreendida pela hierarquia dos "rótulos", pois, apesar de este ter sido enfim reconhecido aos venezuelanos, seu acesso foi, por muito tempo, negado e inibido. Como exposto, a reivindicação pelo reconhecimento do refúgio encontrou espaço no governo Bolsonaro e, apesar do acerto da decisão, é necessário o acompanhamento contínuo desta medida que, nos parece, visa contribuir mais a objetivos de política externa do que, de fato, integrar uma gestão migratória de caráter humanitário no Brasil.

\section{Referências bibliográficas}

ACNUR. ACNUR parabeniza Brasil por reconhecer condição de refugiado de venezuelanos com base na Declaração de Cartagena. 29.07.2019. Disponível em: <https://www.acnur.org/portugues/2019/07/29/acnur-parabeniza-brasilpor-reconhecer-condicao-de-refugiado-de-venezuelanos-com-base-nadeclaracao- de-cartagena/> . Acesso em: 30.10.2020

ACNUR. Global Trends: Forced Displacement in 2019. United Nations High Commissioner for Refugees, 2020.

ACNUR; OIM. Response for Venezuelans. 2020. Disponível em: <https://data2. unhcr.org/en/situations/platform>. Acesso em: 29.10.2020.

BAENINGER, Rosana et al. Migrações Venezuelanas. Campinas, SP: Núcleo de Estudos de População "Elza Berquó" - Nepo/Unicamp, 2018.

BETTS, Alexander. Survival Migration: failed governance and the crisis of displacement. Ithaca: Cornell University Press, 2013.

BRASIL. Lei no. 9.474, de 22 julho de 1997. Define mecanismos para a implementação do Estatuto dos Refugiados de 1951, e determina outras providências. Diário Oficial da União, Brasília: Poder Executivo, 23.12.1997. Disponível em: <http://www.planalto.gov.br/ccivil_03/leis/L9474.htm>. Acesso em: 30.10.2020. 
BRASIL. Resolução Normativa № 23, de 30 de setembro de 2016. Estabelece procedimentos de solicitação de passaporte e viagem ao exterior para pessoasrefugiados e solicitantes de refúgio. Diário Oficial da União, Brasília, 16.12.2016. Disponível em: <https://www.justica.gov.br/seus-direitos/ refugio/anexos/rn-no-23-alterada-pela-28.pdf/@@download/file> Acesso em: 30.10.2020.

BRASIL. Resolução Normativa № 126, de 02 de março de 2017. Dispõe sobre a concessão de residência temporária a nacional de país fronteiriço. Diário Oficial da União, Brasília, 03.03.2017. Disponível em: < https://www.legisweb.com.br/ legislacao/?id=338243>. Acesso em: 30.10.2020.

BRASIL. Portaria Interministerial № 9, de 14 de março de 2018. Dispõe sobre a concessão de autorização de residência ao imigrante que esteja em território brasileiro e seja nacional de país fronteiriço, onde não esteja em vigor o Acordo de Residência para Nacionais dos Estados Partes do MERCOSUL e países associados, a fim atender a interesses da política migratória nacional. Diário Oficial da União, Brasília, 15.03.2018a. Disponível em: < https://www.refworld. org.es/topic,57f504723c,5aaaac654,0, ,.html>. Acesso em: 30.10.2020.

BRASIL. Ministério da Justiça e Segurança Pública. Refúgio em Números. 3a Edição. Brasília: MJSP, 2018b. Disponível em: <https://www.justica.gov.br/seus- direitos/ refugio/anexos/refasgio-em-nasmeros_1104.pdf/@@download/file>. Acesso em: 30.10 .2020 .

BRASIL. Ministério da Justiça e Segurança Pública. Nota Técnica n. ${ }^{\circ}$ 3/2019/ CONARE_Administrativo/CONARE/DEMIG/SENAJUS/MJ PROCESS ONo 08018.001832/2018-01 INTERESSADO: COMITÊ NACIONAL PARA OS REFUGIADOS - CONARE ESTUDO DE PAÍS DE ORIGEM - VENEZUELA. 13.06.2019a. Disponível em: <https://www.justica.gov.br/news/collectivenitf-content-1564080197.57/sei_mj-8757617-estudo-de-pais-de-origemvenezuela.pdf/@download/file>. Acesso em: 30.10.2020.

BRASIL. Nota Técnica n. ${ }^{\circ}$ 12/2019/CONARE_Administrativo/CONARE/DEMIG/ SENAJUS/MJ PROCESSO No 08018.001832/2018-01 INTERESSADO: COMITÊ NACIONAL PARA OS REFUGIADOS - CONARE - ESTUDO DE PAÍS DE ORIGEM VENEZUELA - ADITAMENTO. 03.12.2019b.

BRASIL. Ministério da Justiça e Segurança Pública. Refúgio em Números. 4르 Edição. Brasília: MJSP, 2019c. Disponível em: < https://www.justica.gov.br/seus-direitos/ refugio/anexos/RefgioemNmeros_2018.pdf >. Acesso em: 30.10.2020.

BRASIL. Discurso do Presidente da República, Jair Bolsonaro, durante Solenidade de Passagem de Comando da Operação Acolhida. Palácio do Planalto. 16.01.2020a. Disponível em: <https://www.gov.br/planalto/pt-br/acompanhe-o-planalto/ discursos/2020/discurso-do-presidente-da-republica-jair-bolsonaro-durantesolenidade-de-passagem-de-comando-da-operacao-acolhida-palacio-doplanalto $>$. Acesso em: 30.10.2020. 
BRASIL. Ministério da Justiça e Segurança Pública. Conare concede status de refugiado a quase 8 mil venezuelanos. Brasília: MJSP, 2020b. Disponível em: <https://www.gov.br/mj/pt-br/assuntos/noticias/conare-concede-status-derefugiado-ha-quase-8-mil-venezuelanos > . Acesso em: 29.10.2020.

BRASIL. Ministério da Justiça e Segurança Pública. Perguntas frequentes. Brasília: MJSP, 2020c. Disponível em: < https://www.justica.gov.br/seus-direitos/refugio/ perguntas-frequentes $>$ Acesso em: 30.10.2020.

BRASIL. Solicitações de reconhecimento da condição de refugiado ativas em 19 de outubro de 2020. Brasília: Conare, 2020d. Disponível em: <https://www. justica.gov.br/seus-direitos/refugio/anexos/Ativoseinativos_19.10.2020.CSV> Acesso em: 29.10.2020.

BRENNER, Yermi; FROUWS, Bram. Forced to leave: Comparing Destination Options of Venezuelans and Syrians. Mixed Migration Centre. 21.09.2018. Disponível em: $\quad<$ http://www.mixedmigration.org/articles/forced-to-leave-comparingdestina tion-options-of-venezuelans-and-syrians/> . Acesso em: 30.10.2020.

CORRÊA, Mariana A. S. et al. Migração por sobrevivência: soluções brasileiras. REMHU, Revista Interdisciplinar da Mobilidade Humana, Brasília, v. 23, n. 44, p. 221-236, jun. 2015. Disponível em: <http://www.scielo.br/scielo. php?script =sci_arttext \&pid =S1980-85852015000100221\&lng $=$ en \&nrm =i so $>$. Acesso em: 30.10.2020.

FREIER, Luisa. Understanding the Venezuelan Displacement Crisis. E-International Relations. 28.06.2018. Disponível em: <https://www.e-ir.info/pdf/74606>. Acesso em: 30.10.2020.

GRILLO, Marco. Governo brasileiro concede status de refugiado para mais de 21 mil venezuelanos. O Globo, 05.12.2019. Disponível em: <https://oglobo.globo. $\mathrm{com} / \mathrm{mundo} /$ governo-brasileiro-concede-status-de-refugiado-para-mais-de-21mil-venezuelanos-24120213 > . Acesso em: 30.10.2020.

JUBILUT, Liliana; FERNANDES, Ananda. A Atual Proteção aos Deslocados Forçados da Venezuela pelos Países da América Latina. In: BAENINGER, Rosana et al. Migrações Venezuelanas. Campinas, SP: Núcleo de Estudos de População "Elza Berquó" - Nepo/Unicamp, 2ª̣ed., 2018, p. 164-177.

MARCHAO, Talita. Mercosul impõe nova suspensão à Venezuela. UOL, 05.08.2017. Disponível em: <https://noticias.uol.com.br/internacional/ultimasnoticias/2017/08/05/reuniao-da-cupula-do-mercosul-decide-pela-suspensaopolitica-da-venezuela.htm>. Acesso em: 30.10.2020.

MARTIN, Susan; WEERASINGHE, Sanjula; TAYLOR, Abbie. What is crisis migration? Forced Migration Review, n. 45, p. 5-9, 2014. Disponível em: < http://www. fmreview.org/sites/fmr/files/FMRdownloads/en/crisis/martin-weerasinghe-taylor. pdf > . Acesso em: 30.10.2020.

MENDES, José S. R.; MENEZES, Fábio B. B. Política migratória no Brasil de Jair Bolsonaro: "perigo estrangeiro" e retorno à ideologia de segurança nacional. Cadernos do CEAS: Revista Crítica de Humanidades, Salvador, n. 247, mai./ago., p. 302-321, 2019. 
MOREIRA, Júlia B. Migrações internacionais e refúgio sob a ótica do governo Bolsonaro. Revista Mundorama, 25.11.2019. Disponível em: <https:// mundorama.net/? $\mathrm{p}=26743>$. Acesso em: 30.10.2020.

PEREIRA, Alexandre B. Os usos e abusos político do refúgio. Nexo Jornal, 15.02.2020. Disponível em: <https://www.nexojornal.com.br/ensaio/2020/Osusos-e-abusos-pol\%C3\%ADticos-do-ref\%C3\%BAgio>. Acesso em: 30.10.2020.

ROSSA, Lya Amanda; MENEZES, Marilda A. Entre migrações e refúgio: migrações sul-sul no Brasil e as novas tipologias migratórias. In: BAENINGER, Rosana et al. Migrações Sul-Sul. Campinas, SP: Núcleo de Estudos de População "Elza Berquó" - Nepo/Unicamp, 2018, 2a ed., p. 383-401.

SARTORETTO, Laura. Ampliação da Definição de Refugiado no Brasil e sua Interpretação Restritiva. In: BAENINGER, Rosana et al. Migrações Sul-Sul. Campinas, SP: Núcleo de Estudos de População "Elza Berquó" - Nepo/Unicamp, 2a ed., 2018, p. 383-401.

SILVA, João Carlos J. Uma Política Migratória Reativa e Inadequada: A Migração Venezuelana Para o Brasil e a Resolução №. 126 do Conselho Nacional de Imigração (CNIg). In: BAENINGER, Rosana et al. Migrações Sul-Sul. Campinas, SP: Núcleo de Estudos de População "Elza Berquó" - Nepo/Unicamp, 2aㅡ ed., 2018, p. 637-650.

SILVA, João Carlos J.; ABRAHÃO, Bernardo A. Contradições, debilidades e acertos dos marcos de regularização de venezuelanos no Brasil. Monções: Revista de Relações Internacionais da UFGD, Dourados, v. 8, n. 16, p. 255-278, dez. 2019. ISSN 2316-8323. Disponível em: <http://ojs.ufgd.edu.br/index.php/moncoes/ article/view/9845 > . Acesso em: 30.10.2020.

SILVA, João Carlos J.; BOGUS, Lucia Maria M.; SILVA, Stèfanie A. G. J. Os fluxos migratórios mistos e os entraves à proteção aos refugiados. Revista Brasileira de Estudos de População, Belo Horizonte, v. 34, n. 1, p. 15-30, 2017. Disponível em: <http://www.scielo.br/pdf/rbepop/2017nahead/0102-3098-rbepop-3098a 0003.pdf>. Acesso em: 30.10.2020.

SIMÕES, Gustavo F. Venezuelanos em Roraima: características e perfis da migração venezuelana para o Brasil. 2017. Disponível em: <https://www. kas.de/c/document_library/get_file?uuid=fa9065e2-c184-5655-0c041381156aca09\&groupld =265553 > . Acesso em: 30.10.2020.

SOUZA, Fabricio T. Gestão migratória no Brasil: rumo ao subdesenvolvimento. Lugar Comum, Rio de Janeiro, n. 55, p. 33-48, out. 2019. Disponível em: $<$ http://uninomade.net/wp-content/files_mf/157279191803Gestao\%20migrato\% CC\%81 ria\%20no\%20Brasil\%20rumo\%20ao\%20subdesenvolvimento\%20-\%20 Fabricio\%20Souza.pdf>. Acesso em: 30.10.2020.

ZETTER, Roger. More labels, fewer refugees: remaking the refugee label in an era of globalization. Journal of Refugee Studies, Oxford, v. 20, n. 2, p. 172-192, 2007. 